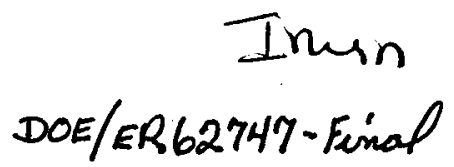

FINAL REPORT

Technology Innovation for Global Change: The Role of Assessment, R\&D, and Regulation DOE Grant \#: DE-FG02-99ER62747.

Principal Investigators: William C. Clark, John P. Holdren, Vicki Norberg-Bohm

November 27, 2001

Through the research carried out under this grant, we have made considerable progress in addressing our fundamental research question: How and under what conditions can government stimulate radical technological innovation? More specifically, we have analyzed three pathways through which government may influence the decisions by firms to invest in radical technological innovation; technological opportunism (supply-push policies), regulatory responsiveness (demand-pull policies) and anticipatory action (assessments and information policy). We have produced several written documents, as well as made several presentations of our work. We are now working on a book based on this research, which we will have to a publisher in 2002. We are also pursuing other opportunities for dissemination of the results, including both presentations and articles in the academic and policy press.

\title{
Research Design
}

We addressed our research question by focusing on the role of government in the development of three technologies: gas turbines, wind turbines, and solar photovoltaics. A key component of this research was in depth interviews at leading firms in each of these industries. The firms that we included in the study are listed below. At each firm, we interviewed high level managerial and scientific personnel. The number of people we interviewed at each firm depended on firm size and organization. At the larger firms, we talked with 8 to 12 people; at the smaller firms it varied, but was generally under 5 . We have also completed extensive archival research on each of these firms and on the government programs that influenced the development and deployment of these technologies. The research also included interviews with Department of Energy, Environmental Protection Agency, and national laboratory personnel.

Gas Turbines

- General Electric

- Siemens-Westinghouse (interviews in Atlanta (formerly Westinghouse) and Munich (formerly

Siemens)

- Enron

Wind Turbines

- Enron Wind (interviews at Enron Headquarters, Houston and Enron Wind, Tehachapi)

- The Wind Company

DOE Patent Clearance Granted

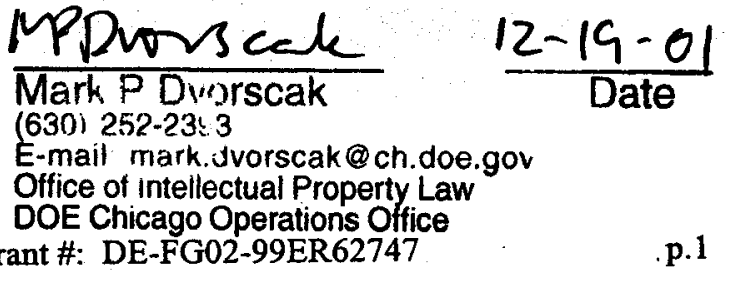

Final Report, Technology Innovation for Global Change, DOE Grant \#: DE-FG02-99ER62747. 
Solar Photovoltaics

- BP (interviews in Maryland (formerly Solarex) and in Britain with BP Solar and BP

Headquarters)

- Siemens Solar (in Munich and in California)

- Evergreen Solar

- Astropower

\section{Results}

Analysis to date has focused on two of the three pathways - supply-push policies and demand= pull policies. We are in the process of analyzing the role of assessment as well as looking at the interaction of these three pathways. We are finding that assessment plays a less direct and generally weaker, but sometimes catalytic role in firms' strategic decisions to invest in technology innovation. We will be drawing lessons on the circumstances under which assessment activities can increase anticipatory action by firms. Below we summarize the some of our initial findings.

Our initial analysis of the first two pathways and their interaction (technological opportunism and regulatory responsiveness) has shed light on the role of government policy in closing the "gap" between invention and commercialization. This gap has recently been called."the valley of death," to describe the fact that many technologies perish after invention but prior to commercialization. Our research suggests that for clean energy technologies, this valley consists of funding, technical and market gaps. We expect these gaps to be wider for clean energy technologies than many other commercial technologies for several reasons: public benefits are not reflected in market prices; there are limited niche markets for many new energy technologies; there is a long time horizon between basic R\&D and proof of principal; and there is often a need for complementary institutional and infrastructure development for new energy technologies to succeed in the marketplace.

Our research found that government policies and programs played a fundamental role in closing all three aspects of this gap. In terms of $R \& D$ funding, government support was critical for moving technologies from concept to proof of principal. For the firms in our sample, from onethird to almost 100 percent of the research budget came from public support. The private funding that firms received was often contingent on winning government contracts. Furthermore, government funding helped firms reach milestones necessary to receive additional funding from private sources. We also found that even for large firms with deep pockets, government support for R\&D was critical for radical innovation. This is for several reasons: financial strength does not necessary translate into innovation for the public good; radical component innovation for mature technologies may be too risky for the private sector; the financial strength of a parent company does not translate into investment in radical innovation; and finally, even for an established technology, a slowdown in the market can reduce the ability to generate internal R\&D funding. In terms of the technology gap, we found that government laboratories provided important complementary assets to private sector efforts in technology innovation, including testing facilities, design review, and in some cases technological knowledge. In terms of the market gap, we found that government support for markets had a 
positive feedback to private seetor investments in technology innovation. This is despite the fact that private funders often expressed cautiousness about investing in technology innovation for government created markets, due to the uncertainty in level and timeframe. In sum, our research suggests that there is the possibility of creating a virtuous cycle in which government programs and policies that simultaneously support both $R \& D$ and markets can stimulate private sector investments that move radical innovations through the learning process that is necessary for them to become commercially competitive.

Our initial analysis of the "technological opportunism" pathway has also focused on evaluating the evolving paradigm for government sponsored R\&D, which emphasizes collaboration and partnership, and includes: cost-sharing, transfer of intellectual property rights to the private sector, funding closer to commercialization, and an increased focus on manufacturing. Within our cases we have looked in depth at three DOE sponsored R\&D collaborations: the Advanced Turbine Systems (ATS) program, the Photovoltaic Manufacturing Technology (PVMaT) project, and the Thin-Film PV Partnership project. We conclude that through collaborative goal setting and implementation, these partnerships moved industry at a faster pace than it would have otherwise gone in the development and commercialization of radical technological innovation. For both gas turbines and PV, this resulted in having better products available for the current rapidly expanding market. In order to achieve these results, the government needed to provide significant cost-sharing, and industry had to believe that the goals were reachable and that the resulting technology would be competitive in the market. In this sense, these programs operated in tandem with energy and environmental regulation that was creating markets for these technologies, both at home and abroad. These programs were focused on near- and mediumterm technological goals. In considering the application of R\&D collaborations for radical innovation that is further from market, two additional issues must be addressed: balancing nearterm and long-term technological goals and integrating evolving environmental science and regulation into project goals. We expect to take up this last point in more depth as we analyze the interaction of our third pathway - anticipating action.

\section{Ongoing Analysis}

The outline for our book is presented below. We have begun discussions with MIT Press on publication of this book.

Working Title: Technology Innovation for Global Change

Chapter 1: Introduction.

Chapter 2: Stimulating Technological Innovation: The Role of Assessment, R\&D, and Regulation

Chapter 3: Public Policy in the Development of Photovoltaics

Chapter 4: Public Policy in the Development of Wind Turbines

Chapter 5: Public Policy in the Development of Gas Turbines

Chapter 6: Bringing Technology through Commercialization: Public Policy and Learning

Chapter 7: Conclusions: Policy Lessons 


\section{Presentations}

In addition to several presentations by Robert Margolis and Vicki Norberg-Bohm in our weekly Science, Technology and Public Policy seminar at the Belfer Center for Science in International Affairs at Harvard University, over the last year, Vicki Norberg-Bohm has presented our work in progress in the following venues:

- Organization for Economic Development, Directorate for Science, Technology and Industry, Workshop on the Environment and Innovation, June 2000

- Energy and Resources Group seminar, University of California, Berkeley, September 2000

- Association for Public Policy Analysis and Management Annual Research Conference, Nov. 2000, in a panel titled, Voluntary, Collaborative and Information Based Environment Policy: A Viable Path to Improve Environmental Performance.

- American Association for the Advancement of Science Annual Meeting, February of 2001 , in a symposium titled The Government's Role in the Commercialization of Environmentally Enhancing Technologies.

Vicki Norberg-Bohm is currently organizing a conference for the Department of Energy on The Government's Role in Technology Innovation, to be held in February 2002. She will be presenting results from this research, as well as inviting 5 other experts to present work on this topic.

\section{Publications}

John P. Holdren, "Energy, Climate Change, and Federal Energy R\&D," chap. 1 in Briefing Book for the Aspen Congressional Seminar on Environmental Policy (Washington, D.C.: Aspen Institute, November 1998).

Holdren, John P., et al (President's Committee of Advisors on Science and Technology, Panel of Energy Research and Development). Powerful Partnerships: The Federal Role in International Cooperation on Energy Innovation. Washington, D.C.: Office of Science and Technology Policy, Executive Office of the President of the United States, 2 August 1999.

Holdren, John P. and Kirk R. Smith et al. "Energy, the Environment and Health." Chap. 3 in World Energy Assessment: Energy and the Challenge of Sustainability. New York: United Nations, 2000.

John P. Holdren. "The Energy-Climate Challenge," in US Policy and the Global Environment: Memos to the President, eds. Donald Kennedy and John A. Riggs (Washington, DC: The Aspen Institute, 2000), 21-44. Also published in issue of Environment 43, no. 5 (2001): 8-21.

John P. Holdren. "Meeting the Energy Challenge," Editorial in Science 291 (February 2001): 945. http://ksgnotes1.harvard.edu/BCSIA/Library.nsf/pubs/energychall 


\section{DISCLAIMER}

This report was prepared as an account of work sponsored by an agency of the United States Government. Neither the United States Government nor any agency thereof, nor any of their employees, makes any warranty, express or implied, or assumes any legal liability or responsibility for the accuracy, completeness, or usefulness of any information, apparatus, product, or process disclosed, or represents that its use would not infringe privately owned rights. Reference herein to any specific commercial product, process, or service by trade name, trademark, manufacturer, or otherwise does not necessarily constitute or imply its endorsement, recom. mendation, or favoring by the United States Government or any agency thereof. The views and opinions of authors expressed hervin do not necessarily state or refiect those of the United States Government or any agency thereof. 


\section{DISCLAIMER}

Portions of this document may be illegible in electronic image products. Images are produced from the best available original document. 
John P. Holdren. "Searching for a National Energy Strategy," Issues in Science and Technology (Spring 2001).

http://ksgnotes1.harvard.edu/BCSIA/Library.nsf/pubs/nat=1-energy

John P. Holdren and Samuel F. Baldwin. "The PCAST Energy Studies: Toward a National Consensus on Energy Rd3 Policy," forthcoming in the 2001 edition of Annual Review of Energy and Environment.

John P. Holdren and Kirk R. Smith, "Energy and the Environment," in World Energy Assessment, ed. José Goldemberg (United Nations Environment Programme, New York, in press).

Robert M. Margolis, Understanding Technological Innovation in the Energy Sector: The Case of Photovoltaics, $\mathrm{PhD}$ dissertation, Princeton University, January 2002.

Robert M. Margolis and Daniel M. Kammen, "Underinvestment: The Energy Technology and R\&D Policy Challenge," Science 285 (30 July 1999).

Robert M. Margolis and Daniel M. Kammen, "Evidence of Under-Investment in Energy R\&D in the United States and the Impact of Federal Policy," Energy Policy Vol. 27 (1999): 575584.

Robert M. Margolis and Daniel M. Kammen, "Energy R\&D and Innovation: Challenges and Opportunities," in The Stanford Reader on Global Climate Change, eds. Stephen Schneider, Armin Rosencranz, and John-O Niles (forthcoming).

Vicki Norberg-Bohm, "Stimulating 'Green' Technological Innovation: An Analysis of Alternative Policy Mechanisms," Policy Sciences 32(1999):13-38.

Jeff Loiter and Vicki Norberg-Bohm, "Public Roles in the Development of New Energy Technologies: The Case of Wind Turbines," Energy Policy 27 (1999): 85-97.

Santiago Bañales and Vicki Norberg-Bohm, "The Role of Regulation and Public Sponsored R\&D in the Development of Atmospheric Fluidized Bed Combustion Technology," (proceedings of the 15th Fluidized Bed Combustion Conference, the American Society Goal Engineers, Savannah, Georgia, May 1999).

Annika Lungren and Vicki Norberg-Bohm, "Solar Photovoltaics in Developing Countries: Expanding the Private Market through Multi- and Bi-lateral Programs," working paper ETP99-03, Massachusetts Institute of Technology, Cambridge, MA, 1999.

Karlynn S. Cory and Vicki Norberg-Bohm, "Policies to Implement Renewable Energy Technologies within Electricity Restructuring: Analysis of the System Benefits Charge," working paper ETP99-04, Massachusetts Institute of Technology, Cambridge, MA, 1999. 
Vicki Norberg-Bohm, "Technology Commercialization and Environmental Regulation: Lessons from the U.S. Energy Sector," in Innovation-Oriented Environmental Regulation: Theoretical Approaches and Empirical Analysis, eds. Jens Hemmelskamp, Klaus Rennings, and Fabio Leone (Heidelberg: ZEW Economic Studies, Physica-Verlag (Springer), 2000.

Vicki Norberg-Bohm, "Beyond the Double Dividend: Public and Private Roles in the Supply of and Demand for Environmentally-Enhancing Technologies," in Innovation and Environment (OECD, 2000).

Vicki Norberg-Bohm, "Creating Incentives for Environmentally Enhancing Technological Change: Lessons from 30 Years of U.S. Energy Policy;" in Technological Forecasting and Social Change (forthcoming).

Vicki Norberg-Bohm and Robert Margolis, "Reaching Environmental Goals through R\&D Collaboration: Lessons from the U.S. Department Of Energy Programs for Gas Turbines and Solar Photovoltaics," paper presented at the Workshop on Voluntary, Collaborative and Information-Based Policies, Belfer Center for Science and International Affairs Harvard University, Cambridge, Massachusetts May 10-12, 2001. Forthcoming as a chapter in Sharing Responsibility: Voluntary, Collaborative and Information-Based Approaches for Reaching Environmental Goals, Bruijn, Theo de and Vicki NorbergBohm, eds. 